\title{
Present forest management structures and policies in temperate forests of Mexico: Challenges and prospects for unique tree species assemblages
}

\author{
by Jessica Wallace ${ }^{1}$, Núria Aquilué1, Chelsea Archambault ${ }^{1}$, Sophie Carpentier ${ }^{1}$, Xavier Francoeur ${ }^{1}$, \\ Marie-Hélène Greffard ${ }^{1}$, Isabelle Laforest ${ }^{1}$, Leopoldo Galicia ${ }^{2}$ and Christian Messier ${ }^{1,3, *}$
}

\begin{abstract}
The temperate forests of Mexico are important economically for many small communities as they provide numerous essential ecosystem services. They also contain the highest biodiversity of oak and pine species in the world. Yet they have not been discussed and investigated as much as other temperate forests. This paper presents these unique temperate forests, the particularities of Mexico's forest management and forestry policies, and some of the main challenges and opportunities forest management poses to Mexican society today. Approximately $80 \%$ of the forests are under some form of collective property called comunidades or ejidos, which means that most forest management is based on small community enterprises and small-scale management. However, all forest management activities are regulated by the federal government through the Ministry of Environment and Natural Resources (SEMARNAT). Although the management of these forests shares many of the current challenges affecting all temperate forests, we discuss three challenges that appear to be unique to Mexico: (1) the difficulties in managing such a high number of pine and oak species; (2) the lack of a wellorganized and integrated forest industry sector; and, (3) the high level of illegal logging thought to be responsible for almost $50 \%$ of the total harvest.
\end{abstract}

Key words: Mexican temperate forests, oak-pine forest, national park, conservation, PES system, community forest management, ecosystem management, biodiversity

\section{RÉSUMÉ}

La forêt tempérée du Mexique, de par les services écosystémiques quelle engendre, contribue de manière importante à l'activité économique de nombreuses petites communautés. Cette forêt arbore aussi la plus grande biodiversité de chênes et de pins au monde. Pourtant, celle-ci a fait lobjet de peu détudes comparativement aux autres forêts tempérées du monde. Cet article présente cette forêt tempérée unique, les particularités de la politique de gestion des forêts ainsi que les défis et opportunités actuels de la foresterie mexicaine. Approximativement $80 \%$ des forêts du Mexique sont gérées sous différentes formes de propriétés collectives, appelées "Comunidades" ou "Ejidos", où la gestion de la foresterie est opérée à petite échelle par les communautés et leurs entreprises. Néanmoins, lensemble des activités d'aménagement de la forêt sont réglementées par le gouvernement fédéral, par l'intermédiaire du Ministère de lenvironnement et des ressources naturelles (SEMARNAT). Bien que la gestion de la forêt mexicaine partage plusieurs des défis actuels qui touchent les autres forêts tempérées du monde, nous portons notre attention sur trois dentre eux qui semblent uniques au contexte mexicain: (1) le défi posé par la gestion d'une telle diversité spécifique de chênes et de pins; (2) le défi relié à labsence d'un secteur industriel intégré et bien organisé; et (3) le défi relié à lexploitation illégale, qui serait responsable de près de $50 \%$ de la récolte totale.

Mots-clés : Forêts tempérées mexicaines, forêt de chêne-pin, parc national, conservation, paiement pour services des écosystèmes: PSE, gestion forestière communale, aménagement ecosystémique, biodiversité

\section{Introduction}

The temperate forests of Mexico represent $17 \%$ of the country's land area and are situated in the mountain ranges of the Sierra Madre Occidental (or Western Mother Mountains, the area of greatest concentration of forest ecosystems in the country); in the Eastern, Southern, and Chiapas Sierras Madres; in the Trans-Mexican Volcanic Belt, in the Northern Oaxaca Mountains; and in the Chiapas Highlands and in various isolated mountains of the Mexican Plateau (Challenger and Soberón 2008; Fig. 1). They are composed mainly of pine and pine-oak species at $1800 \mathrm{~m}$ to $4000 \mathrm{~m}$ elevation, and har- bor broad ecological, faunal and floristic diversity (Rzedowski 1981). In fact, these temperate forests contain the greatest diversity of pine and oak species in the world with $42 \%$ and $33 \%$ respectively, in addition to other many important species from the Juniper and Abies genera (Rzedowski 1993, Valencia 2004, Rzedowski 2006). The mega biodiversity of Mexico's temperate forests is derived from the presence of a varied topography and geology, combined with a vast range of climatic conditions across the territory (González-Espinosa et al. 2004) and the mixing of Nearctic and Holarctic realms (Rzedowski 1981). It is also the result of various disturbances

\footnotetext{
${ }^{1}$ Université du Québec à Montréal, Montréal, Québec, Canada

${ }^{2}$ Instituto of Geografía, Universidad Nacional Autónoma de México

${ }^{3}$ Université du Québec en Outaoauis (UQO)

${ }^{*}$ Corresponding author : ch.messier@gmail.com
} 


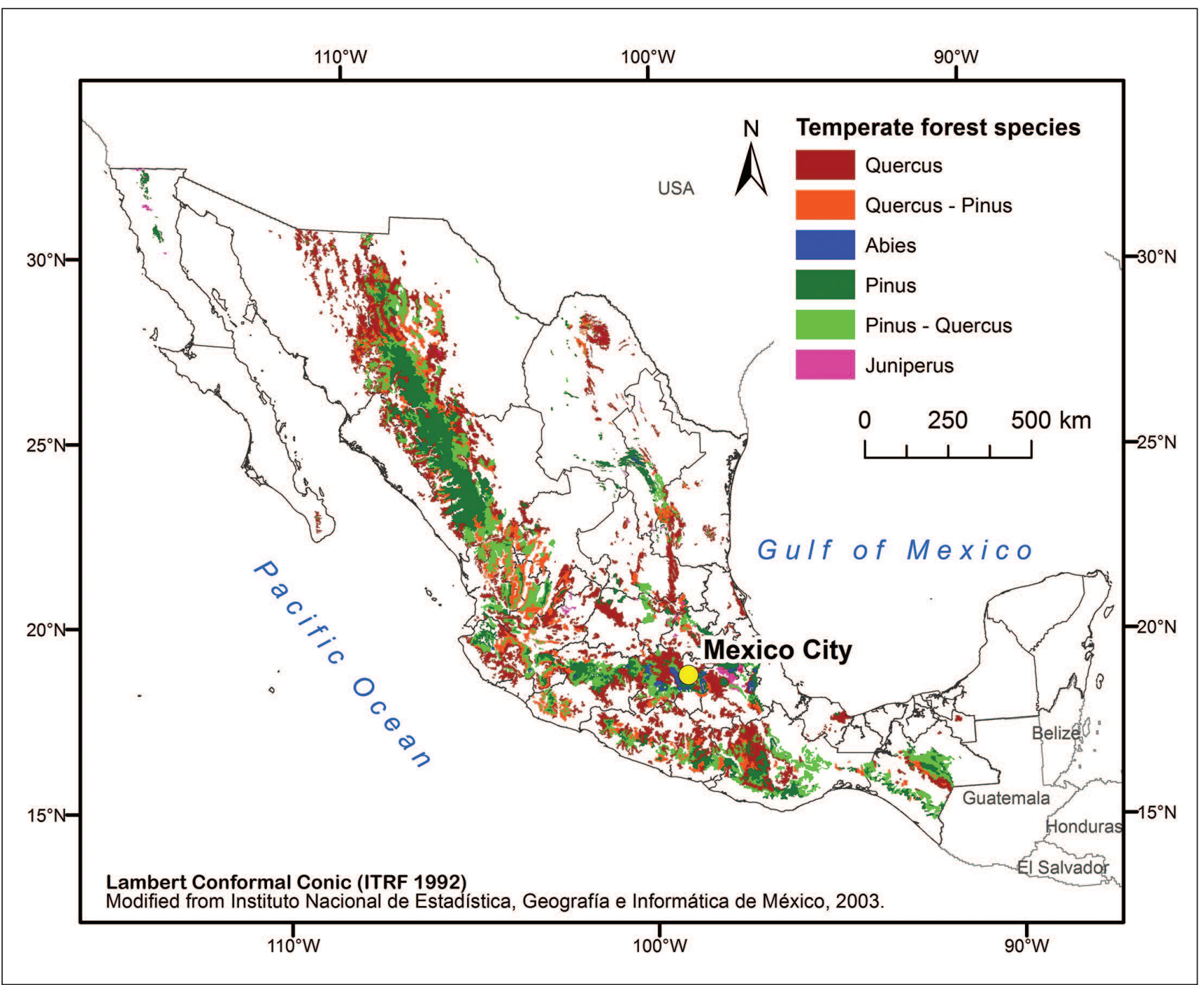

Fig. 1. The distributions of Pinus, Quercus, Abies and other spp. within the temperate forest range.

created by indigenous communities that have historically managed the land using a variety of cultures and systems (Maffi 2005). This rich biodiversity combined with a limited knowledge of the forest species and ecosystem dynamics increases the difficulties forest managers face in protecting and managing these areas.

This paper is the result of a graduate course that included a 10-day visit to Mexico in May, 2014. During the course, the students investigated the ecology, management and conservation of the temperate forests and assisted with a series of conferences by researchers working on these forests. We provide an overview of the main factors and conditions affecting forest management in Mexico. Overall, we focus on the general structure of the country's forestry sector from federal government to local communities. Mainly, we aim at describing: (1) the unique tree species assemblage of these forests; (2) the particularities of Mexico's forest management and forestry policies; and finally, (3) the main challenges and opportunities forest management poses to Mexican society, policy as well as research. We discuss all of these issues based on a review of the recent literature and in light of our trip to Mex- ico and particularly, on our discussions with Mexican professors, forest engineers, park guardians, governmental actors, and investigators.

A unique tree species assemblage: High oak, pine and fir diversity The genus Quercus is well-represented in Mexico with 81 species of white oaks, 76 species of red oaks and four species of golden cup oaks of the 490 species of oak found worldwide (Pérez-Olvera and Dávalos 2008, Bacon et al. 2011). These species are part of different plant communities such as the deciduous oak forests of low altitude in dry climatic areas or the dense evergreen oak forests in more humid areas (Challenger and Soberón 2008). Oaks in temperate forests occur at altitudes between $1800 \mathrm{~m}$ and $3200 \mathrm{~m}$ and are commonly found with Pinus and Abies species (Valencia 2004). Oaks create a considerable challenge for taxonomists when classifying certain groups (Manos et al. 1999) because of the convergent evolution of many tree characteristics (at the interspecific level), high intraspecific trait variation (at the species level), as well as high species similarity among closely related species (Tovar-Sanchez and Oyama 2004, Gonzalez-Rodriguez and 
Oyama 2005). This partly results because oaks frequently undergo hybridization, as this genus is highly outcrossing, wind-pollinated and long-lived (Coart et al. 2002, Dodd and Kashani 2003). New genetic and microscopic technologies such as micromorphologic keys will hopefully clarify taxonomic discrimination in the near future (Scareli-Santos et al. 2013). Oak-forest habitat provides a critical ecosystem for Mexico given that it harbors unique species diversity, constituting one of the most important hotspots for oak diversity in the world (Pérez-Olvera and Dávalos 2008). However, a rapid reduction of this habitat has been observed in recent years as a result of harvesting in some regions of southern Mexico (Wood 1981, Spector and Putz 2006), conversion of forests to cropland (Boucher 1983), pathogen outbreaks such as Ceratocystis fagacearum, known as oak wilt (Appel 1995), and canopy crowding due to fire suppression strategies that favor more shade-tolerant species (Putz et al. 1984). In addition, when oak forests are harvested, early successional pine species rather than oak are increasingly replacing oak forests, and this is especially the case in the southern tropical mountains. This ecological phenomenon is scarcely investigated yet it is overall understood to greatly decrease the biodiversity of these areas (Dr. Leopoldo Galicia, Pers. Comm.). This issue needs further research and discussion (González-Elizondo et al. 2012).

Pinus in Mexico represent two subgenera-Pinus: hard pines and Strobus: soft pines. Of the 110 Pinus species worldwide, 43 are present in Mexico (Styles 1993). This genus also has high intraspecific variation (Hall et al. 2000) which may be attributed to its large populations, processes of speciation and diversification, hybridization with conspecifics and frequent colonization events of new habitats (Barry 1983, Axelrod 1986, Millar 1993). The species is important economically and socially for Mexico, given that it accounts for the majority of the timber produced (Bray and Merino 2005, Merino-Pérez and Segura-Warnholtz 2007). Coherent with how an increase in the occurrence of extreme climatic events and perturbations such as wildfires and bark beetle outbreaks exerts greater stress on species fitness and recruitment in north-western temperate forests (Návar 2014), researchers are working towards developing better tools to assist migration of pine species for successful colonization, many of which are at risk or threatened. Detrimentally, knowledge of each tree species genetic distribution across the latitudinal gradient is scarce (Návar-Cháidez and González-Elizondo 2009, González-Elizondo et al. 2012). New tools forest managers aspire to develop aim at strengthening a species genotype by increasing the expression of frost and drought tolerant genes. However, many pine species have large genomes with long repetitive sequences which are cumbersome and complicates the genome-sequencing task (Kriebel 1985, Wakamiya et al. 1993, Elsik and Williams 2000).

Abies is represented by 10 species of the 50 existing worldwide. The most common is Abies religiosa (Ferrusquia-Villafranca 2007), which mainly occurs in the Trans-Mexican Volcanic Belt's high mountains regions (Sánchez-Velásquez et al. 1991, Jaramillo-Correa et al. 2008). The most well-known forest is the Monarch Butterfly Biosphere Reserve where the firs serve as a migratory destination and repository for the monarch butterfly (Anderson and Brower 1996, Oberhauser and Peterson 2003). Of the dominant, long-lived tree species of temperate forests in Mesoamerica, Abies is among the most under studied. Yet data on Abies religiosa has demonstrated that, since 1971, its distribution has suffered a 55\% reduction in area which is alarming (Rzedowski 2006, SEMARNAT 2008). This tendency is increasing and predicted to reach as high as 92\% within the next 50 years (Rehfeldt et al. 2012). This recent and drastic loss is suggested to result from extreme temperature and/or precipitation events due to largescale climatic variability (Sáenz-Romero et al. 2010, Návar 2014). The loss of the Abies religiosa forest is a threat to monarch butterflies which utilize the trees but also jeopardizes the livelihoods of the people that depend on these forest resources.

These unique pine, oak, and fir assemblages are the basis of timber production in Mexico. For example, 4.6 million $\mathrm{m}^{3}$ of pine (79.0\%), $500000 \mathrm{~m}^{3}$ of oak (8.7\%), and $160000 \mathrm{~m}^{3}$ of fir (2.9\%) were harvested in 2013. Of the total production of timber, conifers (mostly pine and fir) represented $82.4 \%$, while deciduous species (mostly oak) represented $12.2 \%$. The most harvested species are P. engelmannii, $P$. montezumae, $P$. ayacahuite, $P$. patula, $P$. oocarpa, $P$. pseudostrobus, $P$. herrerae, P. leiophylla and P. arizonica (Perry 1991, Le Maitre 1998, Ramírez-Herrera et al. 2005). At a local level, trees provide firewood and timber to build houses and furniture. For example, in northern Mexico P. cembroides is used to produce firewood, charcoal, and to a lesser extent, timber (SánchezGonzález 2008).

Mexico thus offers an exceptional playground for studying the ecology of oak, pine and fir forests, along with processes such as species diversification to better account for their preservation. Considering the importance of these species ecologically, and bearing in mind that many oaks, pines and firs are key species in different types of economic activities in the country, the identification and protection of these temperate species and their habitats is crucial for future economic and overall social well-being.

\section{Particular forest management structures and policies}

Mexican temperate forests are managed by either the federal government for parks and national forests, or by local communities. However, many federal organizations are involved in providing regulation, guidelines and assistance to local communities. This section describes the parks and national forests, the forestry structure and management and the unique community-based forest management systems of Mexico. It then discusses one of the first and most successful incentives for payments for ecosystem services in the world, developed to safeguard water supply.

\section{Parks and national forests}

The Mexican government has created 176 "Natural Areas" which are $12 \%$ of the nation's land area (CONANP 2012). These areas comprise the System of Natural Protected Areas. While most of the parks are not federally owned, the protection of these areas has been consolidated and coordinated by the National Commission of Protected Natural Areas (Comisión Nacional de Áreas Naturales Protegidas, CONANP). CONANP is a federal, decentralized agency of the Ministry of Environment and Natural Resources (Secretaria del Medio Ambiente y Recursos Naturales, SEMARNAT). The agency is responsible for providing protection to parks as 
(a)

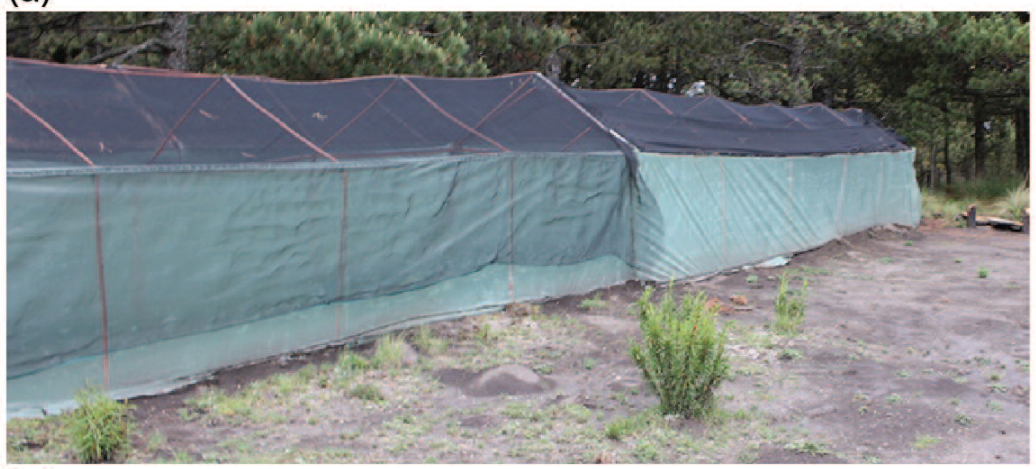

(b)

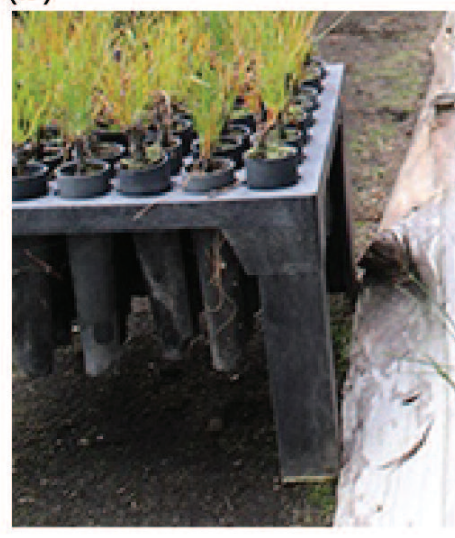

(c)

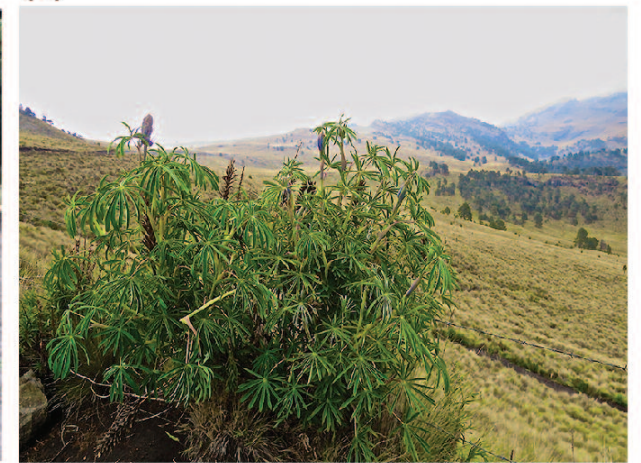

(d)

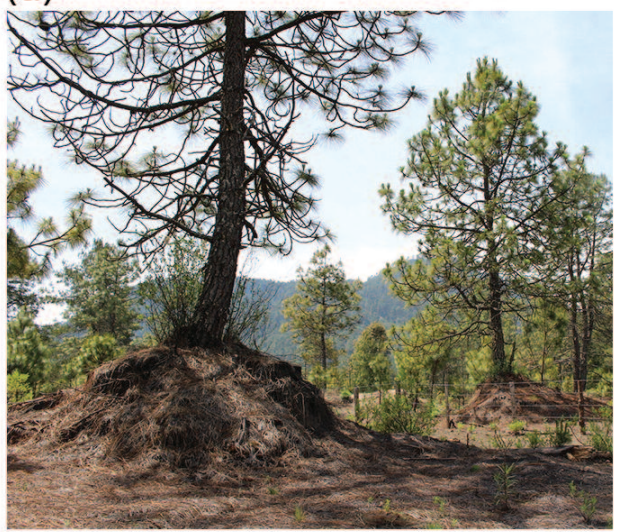

Fig. 2. Reforestation and restoration strategies: (a) nursery at Izta-Popo Zoquiapan National Park; (b) pine seedlings raised in a local nursery; (c) lupin-nurse plant shrub; and, (d) soil removal procedure to permit recruitment of pine after volcanic eruptions have left tephra deposits.

well as overseeing its rapid expansion, as parks are continuously created and added to the network. CONANP is also concerned with maintaining the living conditions of people in the park vicinities as well as providing opportunities for increasing their livelihoods. Parks are thus simultaneously managed from a conservationist - restorative approach while providing some basic ecosystem services and employment for local people.

The Natural Areas are further classified by CONANP into National Parks, Biosphere Reserves, Protected Flora and Fauna Areas, Nature Sanctuaries, Protected Natural Resource Areas, and Natural Monuments. In this discussion we will focus on National Parks and Biosphere Reserves as these areas were originally designed to conserve Mexico's highland forests where temperate forests are found. The following is based on our visit and personal exchanges with SINAP (El Sistema Nacional de Areas Naturales Protegidas) officials at three protected areas: the Izta-Popo Zoquiapan National Park; the National Park of La Malinche; and, the Monarcha Butterfly Sanctuary (Fig. 1). While visiting these parks, we discussed management strategies and observed various techniques implemented by Mexican officials to protect these areas from disturbances, over-grazing, and harvesting.

Global changes are already affecting Mexican highland temperate forests. They include changes in regional climate and climate variability (temperature and precipitation pat- terns), land use, deforestation, and effects from invasive species on native flora and fauna (Galicia et al. 2015). One of the alarming ramifications of these stresses is an adverse effect on forest regeneration and recruitment. In an attempt to mitigate this phenomenon, SINAP officials are transplanting young trees from areas of high to low areas of recrutment, collecting seeds from the forest to grow in nurseries (Fig. 2) and assist migration of the seedlings. Often seedlings with high survival potential are chosen or selectively bred and then planted in areas where high seedling mortality or low recruitment is occurring. However, following natural disturbances (e.g., wildfires, pests, diseases, climate-driven events) that open tree canopies, pines normally colonize these sites successfully (Návar-Cháidez and González-Elizondo 2009). Additionally, seed survivorship may depend on management practices. A widespread and often necessary method in Mexico to permit pine seedling survivorship is to plant seedlings where lupins, referred to as nurse plants, have occurred (Blanco-García et al. 2011). Lupins are legumes that fix nitrogen from the atmosphere into ammonia via a rhizobium-root nodule symbiosis (modulated by Bradyrhizobium soil bacteria), fertilizing the soil for other plants. This adaptation allows lupins to be tolerant of infertile soils and capable of pioneering change in barren and poor-quality soils, including reestablishment of pine habitat, especially at high elevations. Lastly, following volcanic activity, tephra deposits render soils 
(a)

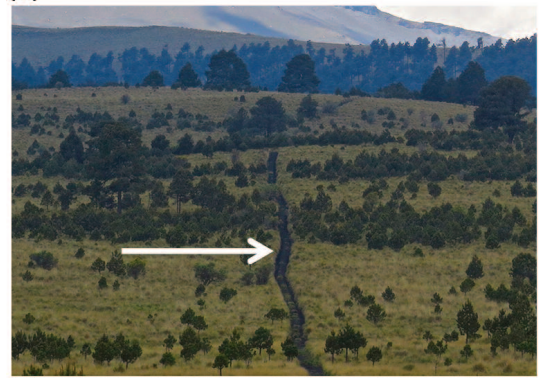

(d)

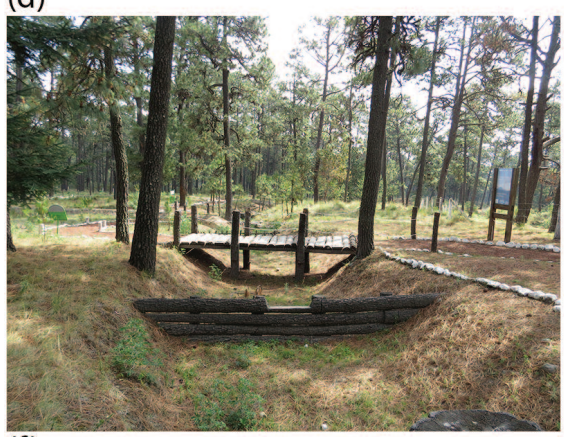

(f)

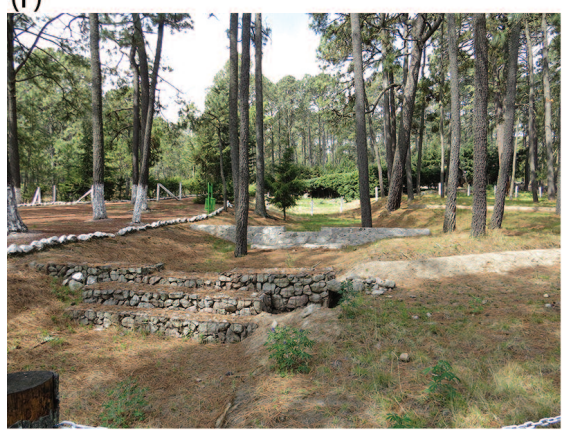

(b)

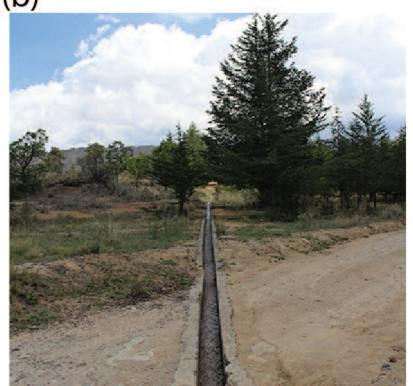

(e)

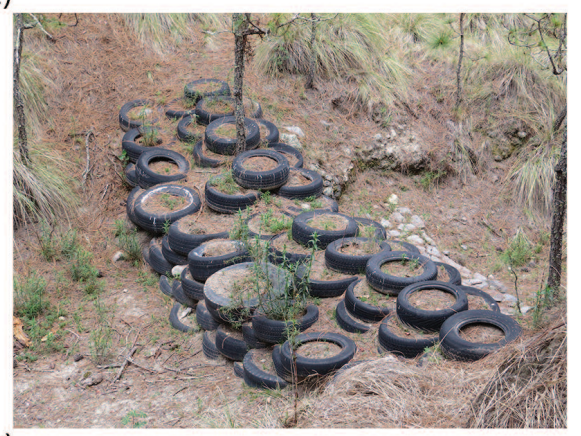

(g)

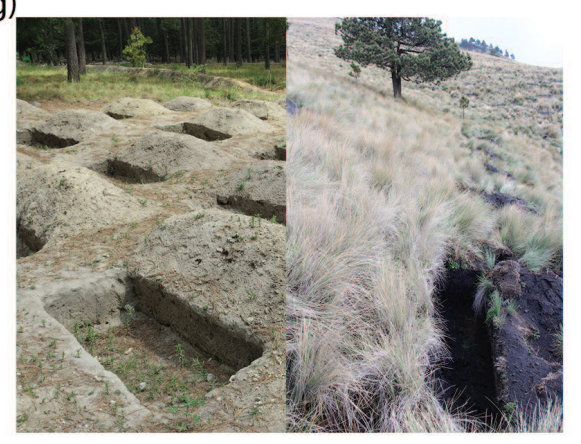

(c)

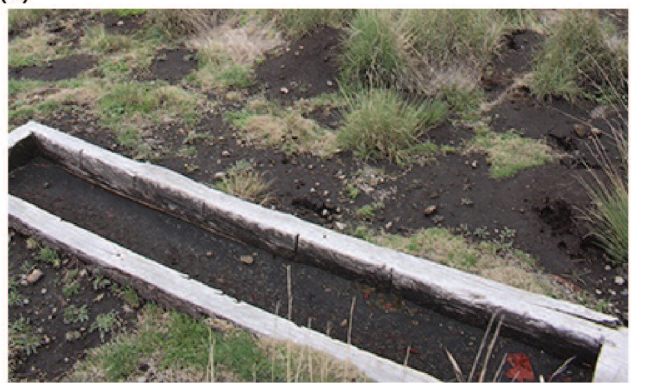

(h)

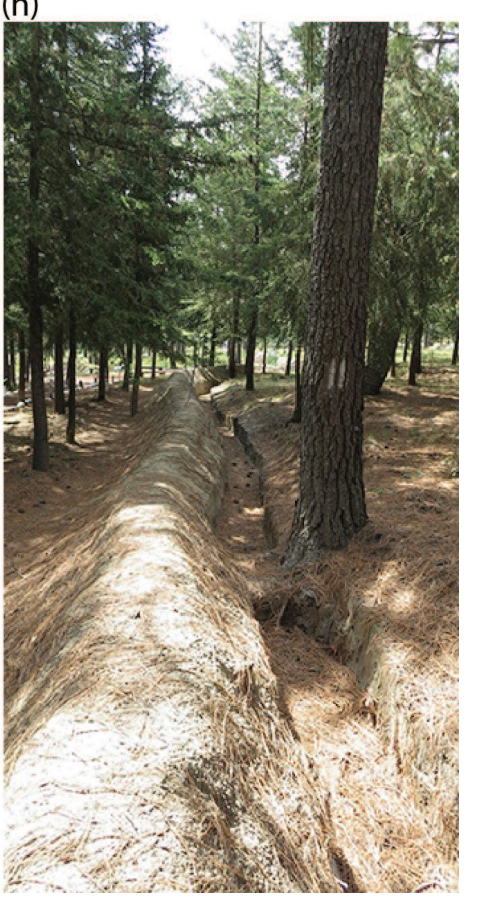

Fig. 3. Fire and water-scarcity management: (a) narrow "path-like" barriers for fire management; (b) aqueduct to provide water to local residents; (c) troughs to create watering hole for fauna and for water retention for forest management and physical structures are implanted in streams to create barriers to water flow using; (d) wood; (e) used-pneumatic tires; (f) cement or stone, or physical structures are imposed via excavation across the landscape in $(\mathbf{g})$ troughs and/or (h) trenches.

incompatible with pine recruitment. Restoration practices to re-establish pine habitat on these soils include manually removing tephra deposits, followed by the application of pine-bark mulch (Blanco-García and Lindig-Cisneros 2005). Thus nurse plant effects have been used as an effective reforestation and restoration strategy, and mulching has also effectively ameliorated adverse soil conditions. However, the use of nurse plants is limited by the presence of suitable nurse species before trees are planted, and use of mulching depends on availability of appropriate materials (Fig. 2).

Another challenge linked to global change is the threat of invasive species (CONABIO and SEMARNAT 2009). For example, in the forests of Baja California Sur, feral pigs are causing soil erosion and affecting recruitment of oaks (Quercus spp.) due to their high predation of acorns and seedlings (Dr. Leopoldo Galicia, Pers. Comm.). Also at Izta-Popo Zoquiapan National Park, there is an ongoing invasive and abundant mole species which preferentially feeds on the roots of pine. It consumes the roots at such a rate that seedling recruitment and adult survival are threatened. Park officials are investing great efforts to maintain a low mole population by cutting the damaged trees.

In addition, climate change is predicted to increase fire frequency and water scarcity (Galicia et al. 2015). These issues are already of concern in many areas during the dry season. At Izta-Popo Zoquiapan National Park, a preventative measure against the spread of fires consists in creating long and narrow strips devoid of vegetation, resembling a footpath within the grassland landscape. These strips act as fire barriers that reduce possible propagation of fire (Fig. 3).

Water scarcity is also a crucial problem that could intensify with climate change. To mediate this in terms of forest restoration measures, physical structures are implanted in streams to create barriers to water flow using wood, cement, stone or used pneumatic tires. These soil and water conservation practices have been funded by the federal government (CONAFOR) and, in some instances, by regional commercial enterprises (such as Coca-Cola and Volkswagen) as well as by 
state governments. In the temperate forests in Central Mexico, thousands of troughs and trenches have been dug across the landscape to retain water (Fig. 2). Although this is an interesting idea, the efficiency of these trenches in affecting water movement has not been demonstrated (Cotler et al. 2013). To provide water for people living further below the high elevations where temperate forests occur, aqueducts run from high to low elevations, and to provide water for fauna, permanent concrete troughs are dug within the park (Cotler et al. 2013). Although these parks and national forests are protected, human-related disturbances still greatly affect these protected areas through both direct and indirect effects. For example, an important indirect effect is cattle grazing. In Mexico, cattle are abundant and are often free to roam or led to graze by individuals. Cattle affect park vegetation by eating or trampling seedlings, new shoots and young trees, thus disrupting forest growth, recruitment, and population dynamics. Cattle grazing and other livestock have been restricted from roaming freely on the landscape of Natural Protected Areas. However, many national parks, including La Malinche and Izta-Popo, have found it necessary to build extensive fences to keep out cattle from their periphery. Unfortunately parks do not always have the resources or financial support to construct these protective barriers nor do they have professionals to monitor livestock exclusion (Dr. Leopoldo Galicia, Pers. Comm.).

The most pervasive, human-related direct effect comes from the legal or illegal usage and exploitation of the protected area for its many resources. The extraction of various forest products is an important factor affecting the quantity and quality of biodiversity in protected areas. Illegal logging, conversion of forest timber into charcoal, and hunting all constitute recurrent problems in Mexico's parks and national forests for which park officials and rangers must patrol and fight against (Dr. Leopoldo Galicia, Pers. Comm.; Fig. 4).

\section{Forestry structure and management}

Although most forestry activities are carried out in community forests, they are regulated by the federal government through the Ministry of Environment and Natural Resources (SEMARNAT). As part of the National Development Plan 2001-2006 (PND), the federal government establishes priorities, strategies and objectives related to the environment and promotion of sustainable development. The PND has provided short-term solutions for overcoming major challenges linked with the forestry sector, but also has provided a longterm vision with the establishment and implementation of the Strategic Forestry Program 2025 (PEF). This aims at promoting and strengthening the sustainable development of forest ecosystems until 2025, and is the first government-endorsed, long-term forest policy program for guiding forest activities.

SEMARNAT is responsible for ensuring forest policies for sustainable use, conservation, protection and restoration of resources and habitat. All legal logging in Mexico (landowners, communities, enterprises), must at all times be approved by SEMARNAT. For instance, it issues, suspends, revokes, invalidates or cancels authorizations for tree planting and exploitation of forest resources in order to ensure forest conservation and functioning ecosystems. Permits are usually valid for a period of 10 years. In 2000, SEMARNAT issued 2 616 permits, representing nearly seven million $\mathrm{m}^{3}$ of timber
(CONAFOR 2001), contributing to about $1.8 \%$ to the Gross Domestic Product (SEMARNAT/CONAFOR 2001). SEMARNAT also develops and evaluates programs for soil rehabilitation in non-forested areas (SEMARNAT/ CONAFOR 2001).

CONAFOR is an independent organization from SEMARNAT and aims to promote and stimulate activities of production, conservation and reclamation of forested land. Jointly with SEMARNAT, it develops and implements federal forest policies, holding a key role for planning sustainable programs. CONAFOR has four main programs: commercial forest plantations; forest development programs; conservation and sustainable management of forest resources; and, a national reforestation program. It promotes the development of commercial forest plantations and mediates the establishment and management of forest species on agricultural land as well as on land that has become barren and devoid of endemic forest vegetation. Commercial plantations are established to secure the provision of wood and timber but also other non-woody materials. To develop a commercial plantation, any landowner or company with authorization to manage the land may apply to the program. However, an important difficulty must be overcome. The start-up cost is high for communities and thus most do not have the capital to make valid their application.

Overall, CONAFOR oversees the reforestation of approximately 200000 ha/yr nation-wide (CONAFOR 2005). With reforestation programs, a major problem is becoming increasingly evident: seedling survival is low and there is a lack of monitoring after planting. Today, survival averages approximately 36\% after the first year (Sheinbaum and Masera 2000). According to Saenz-Romero and Lindig-Cisneros (2004), this low survival is attributed to the seedling genotypes poor adaptation to local environmental and climatic conditions on the reforestation site. This is hardly surprising, considering that CONAFOR's protocol and methodological guidelines are executed uniformly across the country with little consideration for environmental variability (i.e., elevation, precipitation, soil type, temperature) among reforestation sites. This merits greater attention. Particularly, we suggest the protocol should be revisited because such a topdown, uniform approach is unlikely to bring better results in the future, given that overall environmental stress is increasing. Anthropogenic and climatic factors are creating more variation in environmental conditions at multiple spatial scales, which will further increase the need for a more flexible approach to reforestation.

CONAFOR is strongly promoting the sustainable management of temperate forests, and this is especially evident by its commitment to the country's ambitious Strategic Forestry Program 2025 (PEF) plan. Although some excellent examples of community-based forest management exist in Comunidad Ejidal El Tarahumar y Bajíos, Comunidad Indígena de Nuevo San Juan Parangaricutiro Comunal, Comunidad Ixtlán de Juárez and Comunidad Santa Catalina Ixtepeji, it is not the general rule at the national level. For example, only $30 \mathrm{com}-$ munity-based forest enterprises have recognized certification to harvest $2 \%$ of the forested areas of the country. However, many applied measures are not fully compatible with local communities' needs, particularly when considering the high start-up reforestation costs and high seedling mortality. Other 


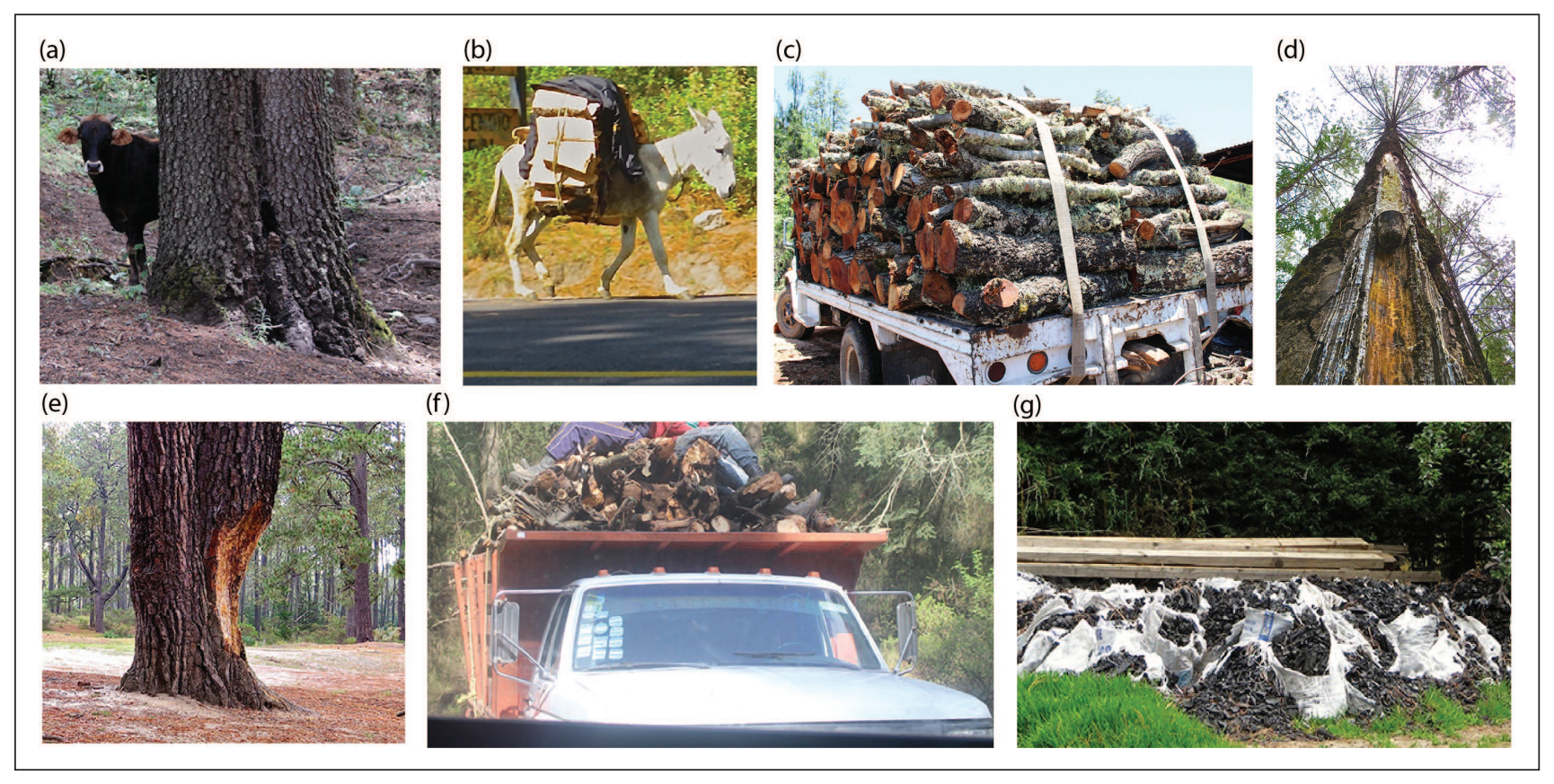

Fig. 4. Challenges for forest preservation: (a) a cow grazing in the Mariposa Monarch Sanctuary; (b) legal extraction of wood products by a local individual; (c) legal commercial wood extraction by selectively logging; (d) legal pine resin collection; (e) illegal extraction of resin covered wood chips to sell as fire starters; (f) illegal logging; (g) sequestered charcoal by park officials as a result of illegal charcoal production.

related social, cultural and economic issues are also restricting good management practices: land tenancy insecurity; poor organization of ejidos and comunidades as units of commercial forest production; a negative import-export balance of forest products; and, a deficient legal and institutional framework that truly promotes sustainable forest management (Bray et al. 2006). It appears that sustainable management of temperate forests requires the consideration and safeguard of local community livelihoods.

\section{Community-based forest management}

In Mexico, 12 million people live in forested areas and most are affected by extreme poverty (CONAFOR 2001). At present, $80 \%$ of forests are under some form of collective property, either as comunidades or ejidos, which are under an ejidal regime (Bray et al. 2003). These are the two main forms of forest-based communities with land tenure following the agrarian reform of the 1930s (Klooster 2003). Comunidades are pre-Hispanic agrarian communities that have demonstrated a long-term occupation of the land, while ejidos have their origins in the Mexican Revolution, and are communities of peasants that manage lands granted by the government. In northern Mexico, ejidos started managing forests in the early 1960s but national level forest-based communities have gained the rights for agroforestry exploitation of their lands since the mid-1980s, in turn taking on the responsibilities associated with the management planning of timber extraction (Bray et al. 2003). Because this requires a linkage to government authorities, Community-based Forest Enterprises (CFEs) were created, which are intercommunity organizations that negotiate on behalf of the communities with government authorities on funding, logging permits and timber prices (Antinori and Bray 2005). Currently, the government legally recognizes over 2400 CFEs and has constituted a community forest enterprise with 600 of them (Bray et al. 2006). Decisions regarding resource use and profit reinvestment are decided within the communities, while appointed managers make recommendations regarding silviculture options through the implementation of a forest management plan that requires the acceptance by SEMARNAT.

CFEs are involved in the support network and decisionmaking process of other secondary businesses that use forest resources-for instance, for furniture construction, refining high-quality resin and providing carpenter suppliers, which creates a linked network between industry players and local markets. The profits of the CFEs are reinvested into both the enterprise and the community itself, providing social benefits such as schools or medical centres. In well-developed communities, CFEs can even act as a funding entity for other smallholders and local economic activities. In Mexico, forest-based communities supported by CFEs have shown to be invaluable for creating fruitful economies, promoting individual engagement in community interests, and generating multiple benefits for livelihoods and cultural well-being (Molnar et al. 2011).In light of conservation and environmental benefits, the forests found within the forest-based communities are often perceived as an alternative scenario to the development of protected natural areas, which show lower deforestation rates (Porter-Bolland et al. 2012). Indeed, the overarching goal of reducing deforestation and increasing biodiversity conservation is shared among ejidos, comunidades, industries and the government (Alix-Garcia et al. 2005). For CFEs to contribute positively to forest and biodiversity conservation, a forest management plan designed by the community and approved 
by the government has to be implemented in the long-term; logging operations need to be strictly controlled and legallyenforced protected areas need to be respected (Bray et al. 2006). While only $12 \%-20 \%$ of ejidos have a forest management plan prepared by a forest technician (CONAFOR 2012), the majority of comunidades and ejidos develop some form of sustainable management plan for their forests to secure their place in the timber market (Bray et al. 2006). However, in many Mexican states, there are ongoing land tenure conflicts because of overlapping governmental reforms, which in turn has caused overwhelming litigation between government officials and private landowners. These conflicts tend to encourage deforestation, illegal logging and social degradation, thus impeding the sustainable use of forest resources (Klooster 2000, Honey-Rosés 2009).

The government recognizes that when communities manage their own forests, this creates employment and strengthens local economies and community well-being, while also maintaining biodiversity conservation. We suggest the government now should further recognize how the provision of technical support for forest management plans via CFEs is crucial, and has the power to benefit biodiversity conservation and community welfare.

\section{Payment for ecosystem services}

Payment for ecosystem services (PES) is defined as a voluntary transaction in which a user buys a specific ecosystem service or set of services from a provider for as long as the service is provided (Engel et al. 2008). Examples of this concept are hydrological services, carbon sequestration, and biodiversity conservation. Thus, this tool is used overall as a means for protecting and/or restoring natural resources. Its application is widespread, with many examples from Latin America (Mayrand and Paquin 2004).

In Mexico, the nation-wide PES program is arguably the government's most innovative environmental program. Launched in 2003 in collaboration with the World Bank, the Payment for Hydrological Services program (PSAH) was created and implemented in response to water scarcity and deforestation problems of the temperate forests surrounding Mexico City. Overexploited watersheds and high rates of deforestation threatened fundamental services. Thus, this program aimed at preserving and ameliorating water for consumption in urban areas. The targeted forests of the program were those found in the upper watersheds that supplied water to high-populated urban areas, but were susceptible of being converted into agricultural land or pastures (MuñozPiña et al. 2008). Following the implementation of this first PES scheme to regulate the water cycle through higher water recharge by forests, other PES schemes were developed for enhancing and securing carbon sequestration, habitat for biodiversity, and agroforestry services such the PSA-CABSA program (Corbera et.al 2009, Shapiro-Garza 2013). Given the efficiency of the program, some respective activities were consolidated. For example, the PSA-CABSA program was merged with the PSAH program under a unifying framework led by CONAFOR, ProÁrbol (Perevochtchikova and Vázquez 2012).

Before the PES policy, the country was delineated in areas of high necessity for forest conservation to regulate the water cycle through aquifer recharge. All ejidos that were part of these delineated areas were considered for PES. These schemes were developed as models for market-based management to recognize the total value of forest and agroforestry ecosystems (SEMARNAT 2008, 2010). The functioning is fairly simple: an owner or a land user (usually an ejido or a comunidad) submits to the program an application that is in turn scored against 26 selection criteria (Romero 2012). Approved projects are registered under a five-year contract with the government. The landowner must then sequester the part of his land that he enrolled in the program to preserve its services, the landowner being paid a certain amount per year per hectare sequestered. Particularly at its onset, enrollment for participation in the PES program was very high, with demand exceeding initial budgets (Alix-Garcia et al. 2009, Corbera et al. 2009). In response, budgets were increased during the following years (González 2008) and the selection criteria were widened. However, even then not all ejidos and comunidades were allowed to apply for this program.

Some caveats were identified following implementation. One important issue was direct competition with other governmental programs, such as subsidies promoting agriculture expansion (Jack et al. 2008, Muñoz-Piña et al. 2008). Secondly, payments to landowners were also said to be too low, widening the economic gap between landowners and nonlandowners (Landell-Mills and Porras 2002, García-Amado et al. 2011). Thirdly, PES schemes do not always sequester land that provides the greatest yield of ecosystems services. For instance, it would have been more profitable for Mexicans to sequester land where aquifers are overexploited, but this was not prioritized by the program (Alix-Garcia et al. 2009). On average, as of 2010, only a small fraction (e.g., $19 \%$ ) of the total possible points that can be given to a site submitted for approval to the program came from environmental criteria (Romero 2012). The other criteria were largely administrative (OECD 2013). This issue can trigger cascading consequences. For example, forests with a low risk of deforestation may be favored by private landowners for PES sequestration over those with high deforestation risks (Engel et al. 2008, Wunder et al. 2008, Alix-Garcia et al. 2012). Leakages, on the other hand, may occur intrinsically when providers chose to increase deforestation at other non-sequestered sites on their land to compensate for the lost opportunity due to their PESsequestered land. In fact, ejidos as well as many other players see PES as additive sources of income and not as substitutive practices (Silva-Flores et al 2010, Pérez-Verdín et al. 2011). All these issues mitigate the net reduction rate of deforestation (Wunder et al. 2008, Alix-Garcia et al. 2012). Even if the overarching goal of PES schemes is to foster the preservation of ecosystem services, they also helped reduce poverty (Pagiola et al. 2005, Pascual et al. 2010). And it is clear that forest owners that participate in a PES program are driven mainly by the opportunity costs of their land. One important question to ask: Is exploitation more profitable than participation in a PES program? (Pagiola et al. 2005, Wunder 2006). If this is the case, exploitation will continue and affect negatively other ecosystem services. It will also encourage plots with the lowest risk of exploitation to be sequestered for biodiversity conservation (Pagiola 2007, OECD 2013).

PES programs worldwide have been both praised and criticized (Mayrand and Paquin 2004, Jack et al. 2008, Corbera et al. 2009, Pattanayak et al. 2010). The Mexican PES program, 
which has been going for more than ten years, provides an invaluable pilot study for discerning crucial forest uses and functions. We anticipate that Mexico will remain a leading country in the implementation of ecosystem-service programs, particularly if it can adapt its PES program such that benefits continue to outweigh its challenges. For instance, in Mexico, PES schemes allowed millions of people to have access to pure water for free, resolving a critical environmental, economic and health issue. Alternatively, there are a few key improvements that we believe could augment the efficiency of expenditure and reduce human labor invested into the program. A better evaluation and selection criteria for participation into the program could help avoid leakages and allow better use of the program's monetary resources (Landell-Mills and Porras 2002, Alix-Garcia et al. 2005, González 2008, Muñoz-Piña et al. 2008). The development of riskassessment and service-monitoring schemes in the establishment of a stable and long-term financial framework could help define expected gross returns and build confidence between users and providers of forest services (Mayrand and Paquin 2004, Corbera et al. 2009, Muradian et al. 2010). Finally, the program could be improved if landowners were directly involved in the design of the program implemented on their land and their knowledge taken into account (AlixGarcia et al. 2009).

\section{Particular challenges and opportunities: Towards more sustain- able management}

The temperate forests and forestry sector of Mexico face many similar challenges and opportunities as other forests and regions of the world: (1) the need to adapt to climate and global changes and other human-induced modifications; (2) the increasing competition of fast-growing species coming from tropical countries or regions; (3) the increasing pressure to protect more forests from any type of exploitation; and, (4) the increasing awareness of the other important ecosystem services provided by forests. However, our review of the literature and visit made us aware of a number of challenges and opportunities particular to the temperate forests of Mexico that warrants further discussion.

First, the extremely high number of pine and oak species can be seen as both a curse and a blessing. With so many species having different ecological and silvicultural requirements as well as different wood chemical and physical properties, the accumulated knowledge for each and every species is obviously poor. This is particularly true for Mexico, where both forestry and ecological research for the temperate forest is lacking (Galicia and Zarco-Arista 2014). This means that only a few pine species are managed for high value-added products and that most oak species are used to make charcoal instead of high-quality timber that could be used for furniture making. On the other hand, with such a diversity of pine and oak species well-adapted to almost all possible climatic conditions, the potential for the temperate forests to adjust to global changes through natural or human-assisted means (such as assisted migration) is high.

Second, the lack of a well-organized and integrated forest industry sector means that no industry has the capability to invest money in research and development to develop the potential the region has to offer in terms of wood products. In most ejidos and comunidades, silvicultural activities (timber harvesting and industrialization) result in part-time seasonal jobs done by non-professional workers. From cutting to transportation to transforming industries, all activities are done with insufficient and inappropriate machinery that negatively impact the environment and increase production costs (CONAFOR 2008). However, in northern Mexico, several forest industries that support research and alternative management practices have proliferated. This is particularly true for oak species, which have been traditionally used for charcoal instead of high-end products. The problem seems to stem from the difficulties of any large company to obtain any guarantee of a steady supply of timber, since production is divided among so many small communities that often lack proper forest management plans and social organization. Of course, the high number of species, each having different chemical and physical properties, makes it even more difficult for any large company to obtain a large volume of wood from the few desirable and well-known species they want.

Because most individual CFEs do not have the resources to do the necessary research and development or to buy sophisticated equipment needed for forest-product transformation (e.g., modern sawmills), increased cooperation between neighboring communities seems necessary to develop the required knowledge, strengthen the wood-supply chain and develop larger and more modern mills. But at the same time, there is a need to develop other new, alternative non-woody products such as edible and medicinal plants, mushrooms and resin (Bray and Merino 2005). We witnessed a perfect example of such new, alternative non-woody products when we visited the community of Nuevo San Juan (Michoacán). In addition to timber production, the community has developed a very lucrative pine resin harvest activity, adding an increased value to the standing forest and an important source of income for the community. To foster local economies as well as to maximize the benefits from forest management, products from the Mexican forest should be as diverse as possible and target strategic markets. For example, in northern temperate forests, other alternative management practices exist such as producing edible mushrooms for local and regional markets, wine from mushrooms, compost from pine bark, and bio-energy from forest residues and liter (CONAFOR 2008, SEMARNAT 2008).

A third and final particular challenge confronting forest managers is related to the high level of illegal logging that occurs in both national parks and communal forests. Officially, illegal logging is thought to be responsible for almost $50 \%$ of the timber harvested (Challenger 1998). Illegal timber harvesting is so uncontrolled that the volume illegally logged has not been totally quantified; but the Federal Office for Environmental Protection (PROFEPA) estimates that illegal logging accounted for about $3495000 \mathrm{~m}^{3}$ annually between 2007 and 2010. However, this amount may be largely underestimated given its clandestine nature (Dr. Leopoldo Galicia, Pers. Comm.). Illegal logging responds to multiple causes: land tenancy insecurity; deficient surveillance of forested lands; lack of job opportunities in some regions; predisposition of the forest industry to trade with illegal timber; corruption of authorities that allow these activities; as well as the existence of organized criminal groups (FAO 2004). Illegal logging is a primary threat to sustainable forest management, lowering community incomes from forest produce and dis- 
couraging local communities to develop any formal management plan. Thus, stronger enforcement of regulations and independent solutions to illegal logging should be envisioned and local community ownership should be enforced. Moreover, it is imperative to implement the laws and regulations of the La Ley General de Vida Silvestre (The Wildlife General Law), as well as the Federal Penal Code that regulates environmental crime, promoting both wildlife and habitat conservation and sustainable management.

\section{Conclusions}

The high diversity, extent and particular socio-economic situations of Mexican temperate forests are still relatively unknown in the rest of the world. But with $42 \%$ and $33 \%$ of the world's pine and oak species, this forest needs to be better understood, studied and preserved. Although it shares many of the current global challenges affecting other forests and regions of the world, the particular environmental, social and economic conditions of this region and its forests demand new and novel approaches to insure its sustainable development. In our 10-day visit, we witnessed many new and innovative approaches that could benefit other forests and regions of the world, particularly regions with similar temperate forests such as Canada and Europe. We conclude by calling for more collaboration and exchanges among those regions that share the remaining temperate forests.

\section{References}

Alix-Garcia, J., A.de Janvry, A.D. and E. Sadoulet. 2005. A Tale of Two Communities: Explaining

Deforestation in Mexico. World Dev. 33: 219-235. doi:10.1016/ j.worlddev.2004.07.010.

Alix-Garcia, J., E.N. Shapiro and K.R. Sims. 2012. Forest conservation and slippage: Evidence from Mexico's national payments for ecosystem services program. Land Econ. 88(4): 613-638.

Alix-Garcia, J., A. de Janvry, E. Sadoulet and J. Manuel. 2009. Lessons learned from Mexico's payment for environmental services program. In: Payment for Environmental Services in Agricultural Landscapes pp. 163-188. Springer New York.

Anderson, J.B. and L.P. Brower. 1996. Freeze-protection of overwintering monarch butterflies in Mexico: Critical role of the forest as a blanket and an umbrella. Ecol. Entomol. 21: 107-116.

Antinori, C. and D.B. Bray. 2005. Community forest enterprises as entrepreneurial firms: Economic and institutional perspectives from Mexico. World Dev. 33: 1529-1543. doi:10.1016/j.worlddev. 2004.10.011.

Appel, D.N. 1995. The oak wilt enigma: Perspectives from the Texas epidemic. Annu. Rev. Phytopathol. 33: 103-118.

Axelrod, D.I. 1986. Cenozoic history of some western American pines. Ann. Mo. Bot. Gard. 73: 565-641.

Bacon, J. R., P. Dávila-Aranda, R. Spellenberg and M.S. GonzálezElizondo. 2011. The taxonomic status of the Mexican oak Quercus undata (Fagaceae, Quercus, Section Quercus). Revista Mexicana de Biodiversidad 82: 1123-1131.

Barry, R.G. 1983. Late Pleistocene climatology. In: Porter SC (ed.). Late quaternary environments of the United States. Minneapolis, University of Minnesota Press pp. 390-407.

Blanco-García, A. and R. Lindig-Cisneros. 2005. Incorporating Restoration in Sustainable Forestry Management: Using Pine-Bark Mulch to Improve Native Species Establishment on Tephra Deposits, Restor. Ecol. 13: 703-709.

Blanco-García A., C. Sáenz-Romero, C. Martorell, P. AlvaradoSosa and R. Lindig-Cisneros. 2011. Nurse-plant and mulching effects on three conifer species in a Mexican temperate forest. Ecol. Engin. 37: 994-998.
Boucher, D.H. 1983. Quercus oleoides (Roble Encino). Costa Rican natural history (ed. by D.H. Janzen), pp. 319-322. The University of Chicago Press, Chicago, Il.

Bray, D.B. and L. Merino. 2005. La experiencia de las comunidades forestales en México. Instituto Nacional de Ecología (INE-SEMARNAT).

Bray, D.B., C. Antinori and J.M. Torres-Rojo. 2006. The Mexican model of community forest management: The role of agrarian policy, forest policy and entrepreneurial organization. For. Pol. Econ. 8: 470-484. doi:10.1016/j.forpol.2005.08.002.

Bray, D.B, L. Merino-Pérez, P. Negreros-Castillo, G. SeguraWarnholtz, J. Torres-Rojo and H. Vester. 2003. Mexico's Community-Managed Forests as a Global Model for Sustainable Landscapes. Conserv. Biol. 17: 672-677.

Challenger, A. 1998. Utilización y Conservación de los Ecosistemas Terrestres de México. Pasado, Presente y Futuro, Comisión Nacional para el Conocimiento y Uso de la Biodiversidad, México, D.F.

Challenger, A. and J. Soberón. 2008. Los ecosistemas terrestres, en Capital natural de México, vol. I: Conocimiento actual de la biodiversidad. Conabio, México, pp. 87-108.

Coart, E., V. Lamote, M. De Loose, E. Van Bockstaele, P. Lootens and I. Roldán-Ruiz. 2002. AFLP markers demonstrate local genetic differentiation between two indigenous oak species [Quercus robur L., and Quercus petraea (Matt.) Liebl.] in Flemish populations. Theor. Appl. Genet. 105: 431-439.

CONABIO and SEMARNAT. 2009. Cuarto Informe Nacional de México al Convenio sobre Diversidad Biológica (CDB). Comisión Nacional para el Conocimiento y Uso de la Biodiversidad y Secretaría de Medio Ambiente y Recursos Naturales.

CONAFOR. 2001. Strategic Forest Program for México 2000- 2005. CONAFOR. 2005. Metas del Programa Nacional de Reforestacion. http://www.conafor.gob.mx/programas_nacionales_forestales/pron are/index.html.

CONAFOR. 2008. Programa Institucional 2007-2012. México.

CONAFOR. 2012. Base de datos Estadísticos. Consulta temática. Recursos forestales.

CONANP. 2012: http://www.conanp.gob.mx/.

Corbera, E., C.G. Soberanis and K. Brown. 2009. Institutional dimensions of Payments for Ecosystem Services: An analysis of Mexico's carbon forestry programme. Ecol. Econ. 68 (3): 743-761. doi:10.1016/j.ecolecon.2008.06.008.

Cotler, H., S. Cram, S. Martinez and E. Quintanar. 2013. Forest soil conservation in central Mexico: An interdisciplinary assessment. CATENA. 104: 280-287.

Dodd, R.S. and N. Kashani. 2003. Molecular differentiation and diversity among the California red oaks (Fagaceae; Quercus section Lobatae). Theor. Appl. Genet. 107: 884-892.

Elsik, C.G. and C.G. Williams. 2000. Retro-elements contribute to the excess low-copy DNA in pine. Mol. Gen. Genet. 264: 47-55.

Engel, S., S. Pagiola and S. Wunder. 2008. Designing payments for environmental services in theory and practice: An overview of the issues. Ecol. Econ. 65: 663-674. doi:10.1016/j.ecolecon.2008.03.011. FAO. 2004. Estudio de tendencias y perspectivas del sector forestal en América Latina al año 2020. Informe Nacional México. 96 pp.

Ferrusquia-Villafranca, I. 2007. Ensayo sobre la caracterizacion y significacion biologica. In: I. Luna, J.J. Morrone and D. Espinosa. (eds.) Biodiversidad del Eje Volcanico Transmexicano. UNAM, Mexico, pp. 7-24.

Galicia, L. and A.E. Zarco-Arista. 2014. Multiple ecosystem services, possible trade-offs and synergies in a temperate forest ecosystem in Mexico: A review. Intern. J. Biodiver. Sci., Ecosyst. Serv. \& Manag. 10 (4): 275-288.

Galicia, L., L. Gómez-Mendoza and V. Magaña. 2015. Climate change impacts and adaptation strategies in temperate forests in central Mexico: A participatory approach. Mitigation and Adaption Strategies for Global Change 20 (1): 21-42.

García-Amado, L.R., M. Ruiz Pérez, F. Reyes Escutia, S. Barrasa García and E. Contreras Mejía. 2011. Efficiency of Payments for 
Environmental Services: Equity and additionality in a case study from a Biosphere Reserve in Chiapas, Mexico. Ecol. Econ. 70 (12): 2361-2368

González, M.J. 2008. Evaluación externa de los apoyos de los servicios ambientales. Ejercicio fiscal 2007. COLPOS-CONAFOR. Available at http://148.223.105.188:2222/gif/snif_portal/administrator/ sistemas/evaluaciones/1232641675_PSA_2007.pdf.

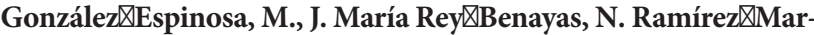
cial, M.A. Huston and D. Golicher. 2004. Tree diversity in the northern Neotropics: regional patterns in highly diverse Chiapas, Mexico. Ecography 27(6): 741-756.

González-Rodríguez, A. and K. Oyama. 2005. Leaf morphometric variation in Quercus affinis and Q. laurina (Fagaceae), two hybridizing Mexican red oaks. Bot. J. Linn. Soc. 147(4): 427-435.

González-Elizondo, M. Socorro, M. González-Elizondo, J.A. Tena-Flores L. Ruacho-González and I. López-Enríquez. 2012. Vegetación de la Sierra Madre Occidental, México: Una síntesis. Acta botánica mexicana, 100: 351-403.

Hall, S.E., W.S. Dvorak, J.S. Johnston, H.J. Price and C.G. Williams. 2000. Flow cytometric analysis of DNA content for tropical and temperate New World pines. Ann. Bot. (Oxford, UK.) 86 (6): 1081-1086.

Honey-Rosés, J. 2009. Illegal Logging in Common Property Forests. Soc. Nat. Resour. 22: 916-930. doi:10.1080/08941920903131120.

Jack, B.K., C. Kousky and K.R.F. Sims. 2008. Designing payments for ecosystem services: Lessons from previous experience with incentive-based mechanisms. PNAS 105 (28): 9465-9470.

Jaramillo-Correa, J.P., E. Aguirre-Planter, D.P. Khasa, L.E. Eguiarte, D. Piñero, G.R. Furnier and J. Bousquet. 2008. Ancestry and divergence of subtropical montane forest isolates: molecular biogeography of the genus Abies (Pinaceae) in southern México and Guatemala. Mol. Ecol. 17: 2476-2490.

Klooster, D. 2000. Institutional Choice, Community, and Struggle: A Case Study of Forest Co-Management in Mexico. World Dev. 28 1-20. doi:10.1016/S0305-750X(99)00108-4.

Klooster, D. 2003. Campesinos and Mexican forest policy during the twentieth century. Lat. Am. Res. Rev. 38: 94-125.

Kriebel, H.B. 1985. DNA sequence components in the Pinus strobus nuclear genome. Can. J. For. Res. 15: 1-15.

Landell-Mills, N. and I.T. Porras. 2002. Silver bullet or fools' gold? A global review of markets for forest environmental services and their impact on the poor: Instruments for sustainable private sector forestry series. International Institute for Environment and Development, London. Available at http://www.cbd.int/doc/external/ iied/iied-silver-report-2002-en.pdf.

Le Maitre, D. C. 1998. Pines in cultivation: A global view. In: M. D. Richardson (ed.). Ecology and Biogeography of Pinus. Cambridge University Press. Cambridge, UK. pp: 407-431

Maffi, L. 2005. Linguistic, Cultural, and Biological Diversity. Annu. Rev. Anthropol. 34: 599-617. doi:10.1146/annurev.anthro.34. 081804.120437.

Manos, P.S., J.J. Doyle and K.C. Nixon. 1999. Phylogeny, biogeography, and processes of molecular differentiation in Quercus subgenus Quercus (Fagaceae). Mol. Phylogenet. Evol. 12: 333-349.

Mayrand, K. and M. Paquin. 2004. Payments for Environmental Services: A Survey and Assessment of Current Schemes. Unisfera International Center (for the Commission for Environmental Cooperation of North America). Available at http://www3. cec.org/islandora/en/item/2171-payments-environmental-servicessurvey-and-assessment-current-schemes-en.pdf.

Merino-Pérez, L. and G. Segura-Warnholtz. 2007. Las políticas forestales y de conservación y sus impactos en las comunidades forestales en México. En: David Barton-Bray, D., Merino Pérez, L., y Barry, D. (eds.). Los bosques comunitarios de México: Manejo sustentable de paisajes forestales. pp 77-98.

Millar, C.I. 1993. Impact of the Eocene on the evolution of Pinus L. Ann. Mo. Bot. Gard. 80: 471-498.
Molnar, A., M. France, L. Purdy and J. Karver . 2011. CommunityBased Forest Management. The extent and potential scope of community and smallholder forest management and enterprises. Washington, DC.

Muñoz-Piña, C., A. Guevara, J.M. Torres and J. Braña. 2008. Paying for the hydrological services of Mexico's forests: Analysis, negotiations and results. Ecol. Econ. 65: 725-736. doi:10.1016/j.ecolecon.2007.07.031.

Muradian, R., E. Corbera, U. Pascual, N. Kosoy and P.H. May. 2010. Reconciling theory and practice: An alternative conceptual framework for understanding payments for environmental services. Ecol. Econ. 69 (6): 1202-1208.

Návar, J. 2014. Hydro-climatic variability and perturbations in Mexico's north-western temperate forests. Ecohydrol. DOI: 10.1002/eco.1564

Návar-Cháidez, J.J. and S. Gonzalez-Elizondo. 2009. Diversidad, estructura y productividad de bosques templados de Durango, México. Polibotánica 27: 71-87.

Oberhauser, K. and A.T. Peterson. 2003. Modeling current and future potential wintering distributions of eastern North American monarch butterflies. Proceedings of the National Academy of Sciences 100: 14063-14068.

OECD. 2013. Biodiversity and forests. In: OECD Environmental Performance Reviews: Mexico 2013. OECD Publishing. pp. 131-156. DOI: 10.1787/9789264180109-en.

Pagiola, S. 2007. Guidelines for "Pro-poor" Payments for Environmental Services. Washington, DC: The World Bank. Available at http://siteresources.worldbank.org/INTEEI/Resources/ProPoorPES-2col.pdf.

Pagiola, S., A. Arcenas and G. Platais. 2005. Can Payments for Environmental Services Help Reduce Poverty? An Exploration of the Issues and the Evidence to Date from Latin America. World Dev. 33: 237-253. doi:10.1016/j.worlddev.2004.07.011.

Pascual, U., R. Muradian, L.C. Rodríguez and A. Duraiappa. 2010. Exploring the links between equity and efficiency in payments for environmental services: A conceptual approach. Ecol. Econ. 69: 1237-1244.

Pattanayak, S.K., S. Wunder and P.J. Ferraro. 2010. Symposium: Environmental Quality and Economic Development: Show Me the Money: Do Payments Supply Environmental Services in Developing Countries? Rev. Environ. Econ. Pol. 4 (2): 254-274.

Perevochtchikova, M. and A. Vázquez. 2012. The federal program of Payment for Hydrological Environmental Services as an alternative instrument for Integrated Water Resources Management in Mexico City. The Open Geography Journal 5: 35-46.

Pérez-Olvera, C. and R. Dávalos-Sotelo. 2008. Algunas características anatómicas y tecnológicas de la madera de 24 especies de Quercus (encinos) de México. Madera y Bosques 14 (3): 43-80.

Pérez-Verdin, G., Y. Kim, J. Navar-Cháidez and R. Silva-Flores. 2011. Valuing Watershed Services in Mexico's Temperate Forests" Modern Econ. 2: 769-779.

Perry, J. P. Jr. 1991. The pines of México and Central America. Timber Press. Portland, Oregon, USA. 231 pp.

Porter-Bolland, L., E.A. Ellis, M.R. Guariguata, I. Ruiz-Mallén, S. Negrete-Yankelevich and V. Reyes-García. 2012. Community managed forests and forest protected areas: An assessment of their conservation effectiveness across the tropics. For. Ecol. Manage. 268: 6-17. doi:10.1016/j.foreco.2011.05.034.

Putz, F.E., R.M. Archibald and G.G. Parker. 1984. Mechanical abrasion and intercrown spacing. Am. Midl. Nat. 112: 24-28.

Ramírez-Herrera, C., J.J. Vargas-Hernández y J. López-Upton. 2005. Distribución y conservación de las poblaciones naturales de Pinus greggii. Acta Botánica Mexicana 72: 1-16.

Rehfeldt, G.E., N.L. Crookston, C. Sáenz-Romero and E. Campbell. 2012. North American vegetation analysis for land use planning in a changing climate: a statistical solution to large classification problems. Ecol. Appl. 22(1): 119-141. 
Romero, H. G. 2012. Payments for Environmental Services: Can They Work? Field Actions Science Reports [Online], Special Issue 6. Retrieved from http://factsreports.revues.org/1711.

Rzedowski, J. 1981. La vegetación de México. Limusa, México, D.F. $342 \mathrm{pp}$.

Rzedowski, J. 1993. Diversity and origins of the Phanerogamic Flora of Mexico. En: Ramamoorthy, T.P., R. Bye, A. Lot y J. Fa (eds.). Biological diversity of Mexico. Origins and distribution. Oxford University Press. NuevaYork.

Rzedowski, J. 2006. Vegetación de México. 1ra. Edición digital, Comisión Nacional para el Conocimiento y Uso de la Biodiversidad. México, pp. 112-113.

Sáenz-Romero, C. and R. Lindig-Cisneros. 2004. Evaluacion y propuestas para el programa de reforestacion en Michoacan, Mexico. Ciencia Nicolaita 37: 107-122.

Sáenz-Romero, C., G.E. Rehfeldt, N.L. Crookston, D. Pierre, R. St-Amant, J. Beaulieu and B. Richardson. 2010. Contemporary and projected spline climate surfaces for Mexico and their use in understanding climate-plant relationships. Clim. Change 102: 595-623.

Sánchez-González, A. 2008. Una visión actual de la diversidad y distribución de los pinos de México. Madera y Bosques 14: 107-120. Sánchez-Velásquez, L.R., M.R. Pineda-López and A. HernándezMartínez. 1991. Distribución y estructura de la población de Abies religiosa (H.B.K.) en el Cofre de Perote, estado de Veracruz, México. Acta Botánica Mexicana 16: 45-55.

Scareli-Santos, C., M.L. Sánchez-Mondragón, A. GonzálezRodríguez and K. Oyama. 2013. Foliar micromorphology of Mexican oaks (Quercus: Fagaceae). Acta Botánica Mexicana 104: 31-52. SEMARNAT. 2008. Informe de la Situacion del Medio Ambiente en México, Mexico.

SEMARNAT. 2008. Proárbol- Programa de Pago por Servicios Ambientales (PSA).

SEMARNAT. 2010. Proárbol - Programa de Pago por Servicios Ambientales Hidrológicos (PSAH).
SEMARNAT/CONAFOR. 2001. Programa Nacional Forestal 20012006. SEMARNAT, México.

Shapiro-Garza, E. 2013. Contesting Market-Based Conservation: Payments for Ecosystem Services as a Surface of Engagement for Rural Social Movements in Mexico. Human Geog. 6(1): 134-150.

Sheinbaum, C. and O. Masera. 2000. Mitigating carbon emissions while advancing national development priorities: The case of Mexico. Clim. Change 47: 259-282.

Silva-Flores, R., G. Pérez-Verdín and J. Návar-Cháidez. 2010. Valoración económica de los servicios ambientales hidrológicos en El Salto, Pueblo Nuevo, Durango. Madera y Bosques 16: 31-49.

Spector, T. and F.E. Putz. 2006. Crown retreat of open-grown southern live oaks (Quercus virginiana) due to canopy encroachment in Florida, USA. Forest Ecol. Manage. 228: 168-176.

Styles, B.T. 1993. Genus Pinus: a Mexican purview. In: Ramamoorthy, T.P., Bye, R., Lot, A., Fa, J. (eds.). Biological diversity of Mexico: Origins and distribution. Oxford University Press, New York, USA. pp. 397-420.

Tovar-Sánchez, E. and K. Oyama. 2004. Natural hybridization and hybrid zones between Quercus crassifolia and Quercus crassipes (Fagaceae) in Mexico: Morphological and molecular evidence. Am. J. Bot. 91(9): 1352-1363.

Valencia, S. 2004. Diversidad del género Quercus (Fagaceae) en México. Boletin de la Sociedad Botanica de México 75: 33-53.

Wakamiya, I., R. Newton, J.S. Johnston and H.J. Price. 1993. Genome size and environmental factors in the genus Pinus. Am. J. Bot. 80: 1235-1241.

Wood, V.S. 1981. Live oaking: Southern timber for tall ships. Naval Institute Press, Annapolis, MD.

Wunder, S. 2006. Payments for Environmental Services: Some Nuts and Bolts. CIFOR, Bogor, Indonesia.

Wunder, S., S. Engel and S. Pagiola. 2008. Taking stock: A comparative analysis of payments for environmental services programs in developed and developing countries. Ecol. Econ. 65(4): 834-852. 